\title{
The Implementation of Kampus Merdeka Program and the Survey of Students Perception on Online Learning at the Prodi Pendidikan Bahasa dan Sastra Indonesia Universitas Negeri Medan
}

\author{
$1^{\text {st }}$ Achmad Yuhdi ${ }^{1}, 2^{\text {nd }}$ Frinawaty L. Barus ${ }^{2}, 3^{\text {rd }}$ M. Joharis Lubis ${ }^{3}$ \\ \{achmadyuhdi@gmail.com ${ }^{1}$, frinawaty@gmail.com ${ }^{2}$, joharis@gmail.com ${ }^{3}$ \} \\ Universitas Negeri Medan, Indonesia ${ }^{1,2,3}$
}

\begin{abstract}
This study intends to describe the level of students satisfaction of the Program Studi Pendidikan Bahasa dan Sastra Indonesia, Universitas Negeri Medan (hereinafter abbreviated as PBSI FBS Unimed) after participating in online learning for the even semester of the 2020-2021 academic years. Moreover, this study also describes the implementation of the Kampus Merdeka Program through the activity of Kampus Mengajar dan Pertukaran Mahasiswa Merdeka (Campus Learning and the Merdeka Students' Exchange) in the study program. The respondents in this activity were 111 students. The research was conducted by using descriptive method. The research data were obtained from observations and interviews with the informants related to the implementation of the Kampus Merdeka Program, while the data of the students' satisfaction survey were obtained through filling out the questionnaires by respondents conducted online via the google form the provided link. The statement instrument filled by the respondent was 7 statements. Derived from the study the results, it was found that the level of the students' satisfaction with the lecturer services in online learning was in the category of positive perceptions with an average score of $72 \%$. Meanwhile, the statements related to facilitating the students' task problem solving by conducting FGDs were still rated negative with a score of $20.7 \%$. Concerning the implementation of the Kampus Merdeka Program at PBSI FBS Unimed, 2 activities were carried out in the form of a teaching campus which was attended by 61 students in batch 1 and a decrease in the number of students in batch 2 to 19. On the other hand, the Exchange of Merdeka Students activity was carried out based on the cooperation that built with the Language and Language Education Study Program. Indonesian Literature from Universitas Negeri Padang UNP), Universitas Sebelas Maret Surakarta (UNS), Universitas Negeri Semarang (UNNES), dan Universitas Negeri Jakarta (UNJ), Universitas Negeri Yogyakarta (UNY), Universitas Negeri Malang (UM), Universitas Pendidikan Indonesia (UPI), and Universitas Negeri Surabaya (UNESA).
\end{abstract}

Keywords: Kampus Merdeka program, students' perception, online learning.

\section{Introduction}

The learning process in the Kampus Merdeka Program is one of the very essential manifestations of the student centered learning. The learning in the Kampus Merdeka provides challenges and opportunities for the development of innovation, creativity, capacity, 
personality, and the students' needs, as well as developing the independence in seeking and finding knowledge through realities and field dynamics such as ability requirements, real problems, social interaction, collaboration, self-management, performance demands, targets and achievements. Through Merdeka learning program which is well designed and implemented, the students' hard and soft skills will be formed strongly [1]. The Merdeka Learning Program launched by the Ministry of Education and Culture is also expected to be able to answer the future challenges of the industrial revolution 4.0 and the era of society 5.0. Due to the rapid development of technology, many sides are worried and predict that their current job will be replaced by technology [2].

The Kampus Merdeka Program is in line with the concept of independent learning. What is meant by independent learning is related to several other terms: (1) self-regulated learning, (2) self-regulated thinking, (3) self-directed learning, (4) self-efficacy, and (5) self-esteem. The meanings of the five terms above are not exactly the same but have some characteristics in common [3]. Learning independence can be interpreted as a form of awareness that arises from within oneself who wants to receive information, manage it, and connect one part of the information to another as [4] explain. And then [5] adds that "learning independence is a person's perception or view of himself, which is formed through experience and interaction with the environment and is influenced by people who are considered important." [6] describe that learning independence is an attitude and behavior in a person to carry out independent learning activities based on his own motivation and is the result of his own experience and practice without relying on others to master certain material, so it can be used to solve the problem at hand.

Regarding this, the policy of Merdeka Belajar-Kampus Merdeka is in line with the Regulation of the Minister of Education and Culture (Permendikbud) Nomor 3 tahun 2020 Standar Nasional Pendidikan Tinggi. The regulation is implemented by a number of related sides, including universities (PT), faculties, study programs, students, and partners. For university managers, it is obligatory to facilitate the students' rights (can be taken or not) to: (a) be able to take credits outside of tertiary institutions for a maximum of 2 semesters or equivalent to 40 credits and (b) can take credits in different study programs at universities the same height as much as 1 semester or equivalent to 20 credits. For the faculty, they must (a) prepare facilitation of a list of faculty-level courses that students can take across study programs and (b) prepare a collaboration document (MoU/SPK) with relevant partners.

On the other hand, for study programs, they are required to: (a) compile or adapt the curriculum to the implementation model of an independent campus, (b) facilitate students who will take cross-study learning in higher education institutions, (c) offer courses that can be taken by students outside the study program and the university and their requirements, (d) conduct the equivalence of courses with learning activities outside the study program and the university, and (e) if there are courses/credits that have not been fulfilled from learning activities outside the study program and the university, alternative courses are prepared online lectures. For the students, they must (a) plan together with their academic supervisor to identify the courses/ programs that will be taken outside the study program, (b) register for activities outside the study program, (c) complete the requirements for activities outside the study program, including participating in the selection if any, and (d) participate in activities outside the study program in accordance with the provisions of existing academic guidelines. Finally, for partners, they must (a) make a cooperation document (MoU) with the university/faculty/study program and (b) carry out an activity program outside the study program in line with the provisions contained in the cooperation document (MoU/SPK). 
This study aims to describe the implementation of the Kampus Merdeka Program carried out by the PBSI Study Program. This study focuses on the implementation of 2 forms of activity, they are students' exchange and campus teaching. Meanwhile, 6 other activities (industrial internships, entrepreneurship, village building, research or research, humanitarian projects, and independent studies are no carried out in the even semester of 2020-2021. Additionally, this study also conducted a survey of the students' satisfaction on the implementation of online learning that carried out during the even semester of 2020-2021.

Several research results related to the implementation of the Kampus Merdeka Program include [7], [8], [9], [10], [11], [12] and [13]. These previous studies describe the implementation and success as well as the problems that arise from the implementation of the Kampus Merdeka program at their respective higher education institutions. Furthermore, writing this article aims to describe the implementation of the merdeka belajar program at the PBSI FBS Unimed Study Program, both independently and through program activities carried out by the Ministry of Education and Culture-Dikti. In the implementation of the program, there is a connection between the Kampus Merdeka Learning material and all the potential in all sectors so that it can explore regional advantages so that this becomes the strength of the study program [14].

\section{Method}

This study used a qualitative approach through a naturalistic method. In qualitative research, the process of processing the data is obtained from the field through interviews and tends to be exposed to words or sentences, and not using statistical calculation numbers. The steps taken are observation, and measurement the students' satisfaction. There were 111 respondents who filled out the satisfaction assessment instrument for the lecture services.

This study used an online questionnaire as the data collection instrument. The questionnaire was created using Google Forms consisting of 7 (seven) question items. The questions are related to whether the lecturer has some teaching materials in the form of handouts, power points, and textbooks (Q1), the lecturer provides an opportunity to ask/answer (Q2), the lecturer explains 6 forms of assignment (Q3), the lecturer discusses the assignments results (Q4), the lecturer facilitates the students in completing the project assignments (Q5), the lecturer acts objectively and non-discriminatory (Q6), the lecturer completes the entire number of meetings (Q7) as shown Table 1 below.

Table 1. Categories of Perception Statements.

\begin{tabular}{cl}
\hline No & Perception Statement \\
\hline $\mathbf{1}$ & $\begin{array}{l}\text { The lecturer has teaching materials in the form of handouts, power point slides, } \\
\text { learning videos, diktat, modules, or textbooks in online learning }\end{array}$ \\
\hline $\mathbf{2}$ & $\begin{array}{l}\text { The lecturer provides opportunities to ask/answer/argue and discuss in the online } \\
\text { learning process }\end{array}$ \\
\hline $\mathbf{3}$ & $\begin{array}{l}\text { The lecturer explains the } 6 \text { forms of assignments given (routine assignments, } \\
\text { critical book reports, critical journal reports, mini research, idea engineering, and } \\
\text { projects.) } \\
\mathbf{4}\end{array}$ \\
$\begin{array}{l}\text { The lecturer discusses the results of case study assignments (Mini Research) } \\
\text { The lecturer facilitates the students in carrying out project assignments to solve } \\
\text { problems by conducting FGD }\end{array}$ \\
\hline
\end{tabular}


6 The lecturer acts objectively and do not discriminate in the assessment.

7 The lecturer completes the number of learning meetings according to the RPS

Related to the responses to the questionnaire, a 5-option Likert Scale was used for each question. The scale in the perception category is from 1 - excellent, 2 - very good, 3 average, 4 - poor, and 5- very poor as shown Table 2 below.

Table 2. Likert Scale in Perception Category.

\begin{tabular}{cl}
\hline No & Selection \\
\hline $\mathbf{1}$ & Excellent \\
\hline $\mathbf{2}$ & Very Good \\
\hline $\mathbf{3}$ & Average \\
\hline $\mathbf{4}$ & Poor \\
\hline $\mathbf{5}$ & Very Poor \\
\hline
\end{tabular}

The data analysis used was qualitative data analysis. For the frequency of responses in the questionnaire, the statistical data were not analyzed manually by the researcher but were calculated and displayed automatically by google form in real time data based on each statement and criteria ( 1 - excellent, 2 - very good, 3 - average, 4 - poor, and 5- very poor). The researcher took statistical data and presented it in the findings and discussion section of the research results.

\section{Results and Discussion}

\subsection{The Implementation of Kampus Merdeka Program}

The implementation of the Kampus Merdeka program in the Indonesian Language and Literature Education Study Program was carried out in 2 activities, they are teaching in schools and the students' exchange for the country or what is called "Permata Sari". In participating in teaching activities at school, the college students first register on the website https://kampus-merdeka-kemdikbud.go.id/. After being declared to have passed the administrative selection, they are then guided by field supervisors assigned by the Ministry of Education and Culture from several universities in North Sumatra to carry out teaching activities in schools for 10 weeks. In this program the number of the students who passed the selection of Class 1 Teaching Campus activities was 61 of the 108 registered students. This number decreased in batch 2, which was 19 out of 25 students. The description of the changes in the data can be seen in the following graph. 


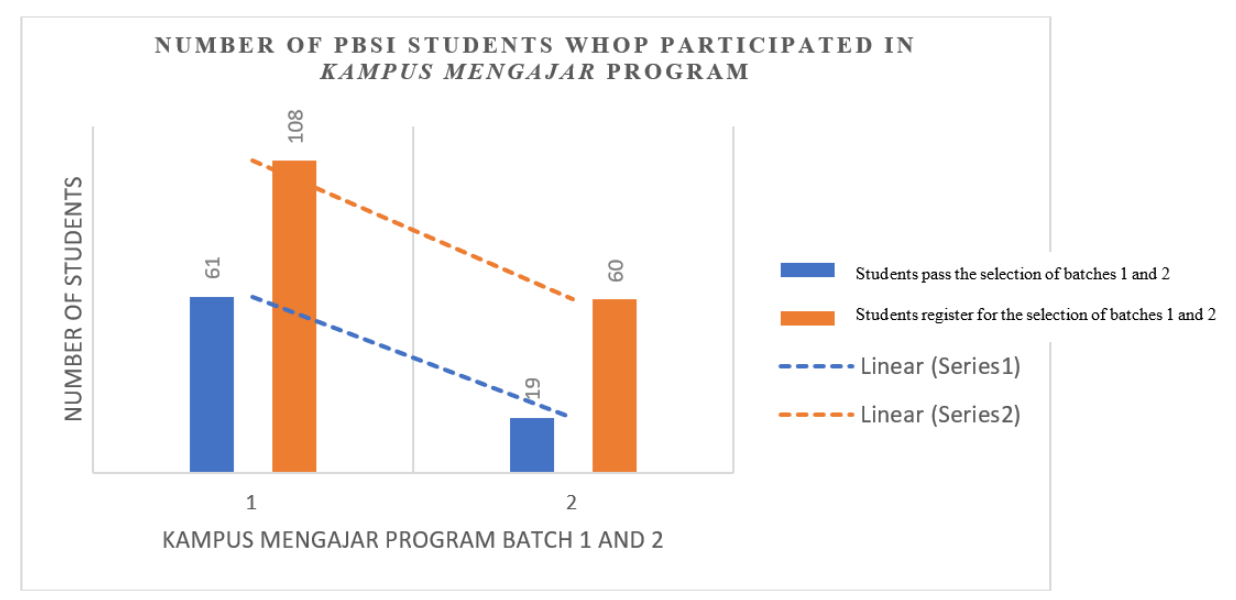

Fig. 1. Graph of decreasing interest in Prodi PBSI students who participated in the Kampus Mengajar Programs.

Derived from the interviews results with several student informants who participated in the Kampus Merdeka program batch 1, it was found that there was disappointment from the participants who received the "Bidik Misi" scholarship program because they did not receive a fee incentive like other regular students. Moreover, another problem that arises in the teaching campus program batch -1 is the unclear course value conversion system so that students besides attending the campus teaching program also attend lectures and do a lot of lecture assignments. This situation is the cause of the declining interest of PBSI Study Program students to take part in the campus teaching program in batch -2 in 2021 .

Besides Kampus Mengajar, another activity carried out in the Kampus Merdeka Program at the PBSI Study Program in 2021 is the "Merdeka Students' Exchange" among the universities. This activity was carried out through the selection of course registration at the Ministry of Education and Culture level and also based on the collaboration that had been built with the Indonesian Language and Literature Education Study Program from Universitas Negeri Padang UNP), Universitas Sebelas Maret Surakarta (UNS), Universitas Negeri Semarang (UNNES), dan Universitas Negeri Jakarta (UNJ), Universitas Negeri Yogyakarta (UNY), Universitas Negeri Malang (UM), Universitas Pendidikan Indonesia (UPI), and Universitas Negeri Surabaya (UNESA) as shown in the following table.

Table 3. Number of Inbound and Outbound Students for Merdeka Students' Exchange Activities.

\begin{tabular}{lcccccccccc}
\hline Note & UNP & UNJ & UNY & UNNES & UM & UNESA & UNM & UPI & UNS & TOTAL \\
\hline $\begin{array}{l}\text { Inbond } \\
\text { Students }\end{array}$ & 30 & 23 & - & 30 & - & - & - & - & 84 & 167 \\
\hline $\begin{array}{l}\text { Outbond } \\
\text { Students }\end{array}$ & 15 & 20 & - & 47 & - & - & - & - & 74 & 156 \\
\hline
\end{tabular}

Derived from the data above, it can be seen that there are PBSI Study Program students from UNP, UNJ, UNNES, and UNS who participated in the Merdeka Students' Exchange Program at Unimed, and the students of Unimed PBSI Study Program who participated in the Merdeka Students' Exchange at the university. The learning is carried out online through an 
online learning model that is face-to-face (synchronous) and through a mutually agreed learning management system (asynchronous). For the students from the PBSI Study Program, especially who come from other universities who carried out activities at FBS Unimed, the learning was carried out through SIPDA (online learning information system) on the elearningfbsunimed website.

\subsection{The Students' Perception}

This section presents the statement scores of the students' satisfaction with the quality of services provided by the lecturers in lecturing activities at the Indonesian Language and Literature Education Study Program as shown in Table 4 below.

Table 4. Data Description of the Students' Perception towards The Lecturing Service.

\begin{tabular}{|c|c|c|c|c|c|c|c|c|c|c|c|c|c|c|c|}
\hline & \multirow{2}{*}{ Kriteria } & \multicolumn{2}{|c|}{ QP1 } & \multicolumn{2}{|c|}{ QP2 } & \multicolumn{2}{|c|}{ QP3 } & \multicolumn{2}{|c|}{ QP4 } & \multicolumn{2}{|c|}{ QP5 } & \multicolumn{2}{|c|}{ QP6 } & \multicolumn{2}{|c|}{ QP7 } \\
\hline & & $\mathrm{F}$ & $\%$ & $\mathrm{~F}$ & $\%$ & $\mathrm{~F}$ & $\%$ & $\mathrm{~F}$ & $\%$ & $\mathrm{~F}$ & $\%$ & $F$ & $\%$ & $F$ & $\%$ \\
\hline \multirow{3}{*}{$\begin{array}{l}\text { Persepsi } \\
\text { Positif }\end{array}$} & baik sekali & 51 & 45,9 & 0 & 0 & 0 & 0 & 0 & 0 & 0 & 0 & 0 & 0 & 0 & 0 \\
\hline & baik & 28 & 25,2 & 82 & 73,9 & 62 & 55,9 & 52 & 46,8 & 55 & 49,5 & 80 & 72,1 & 77 & 69,4 \\
\hline & subtotal & 79 & 71,2 & 82 & 73,9 & 62 & 55,9 & 52 & 46,8 & 55 & 49,5 & 80 & 72,1 & 77 & 69,4 \\
\hline \multirow{2}{*}{$\begin{array}{l}\text { Persepsi } \\
\text { Netral }\end{array}$} & netral & 14 & 12,6 & 25 & 22,5 & 39 & 35,1 & 44 & 39,6 & 33 & 29,7 & 28 & 25,2 & 30 & 27 \\
\hline & subtotal & 14 & 12,6 & 25 & 22,5 & 39 & 35,1 & 44 & 39,6 & 33 & 29,7 & 28 & 25,2 & 30 & 27 \\
\hline \multirow{4}{*}{$\begin{array}{l}\text { Persepsi } \\
\text { Negatif }\end{array}$} & buruk & 15 & 13,5 & 3 & 2,7 & 8 & 7,21 & 7 & 6,31 & 13 & 11,7 & 2 & 1,8 & 3 & 2,7 \\
\hline & $\begin{array}{l}\text { buruk } \\
\text { Sekali }\end{array}$ & 3 & 2,7 & 1 & 0,9 & 2 & 1,8 & 8 & 7,21 & 10 & 9,01 & 1 & 0,9 & 1 & 0,9 \\
\hline & subtotal & 18 & 16,2 & 4 & 3,6 & 10 & 9,01 & 15 & 13,5 & 23 & 20,7 & 3 & 2,7 & 4 & 3,6 \\
\hline & total & 111 & 100 & 111 & 100 & 111 & 100 & 111 & 100 & 111 & 100 & 111 & 100 & 111 & 100 \\
\hline
\end{tabular}

Derived from the data in the table above, QP1 shows the percentage of the respondents' answers to statement number 1 "The lecturer has teaching materials in the form of handouts, power point slides, learning videos, diktat, modules, or textbooks in online learning" in terms of whether the teaching materials owned lecturers are good or not according to students. From the score obtained, it shows that the majority of the respondents was $71.2 \%$ considered that the quality of teaching materials prepared by lecturers is good/satisfactory. There are $12.6 \%$ of the students' perceptions that show an average score, and there are still $16.2 \%$ of negative perceptions (poor $13.2 \%$ and very poor $2.7 \%$ ) given by students regarding the student's assessment of the teaching materials used. lecturers when carrying out online learning.

Related to the QP2 frequency value in table 4 shows the percentage of the respondents' answers to statement number 2 "The lecturer provides opportunities to ask/answer/argue and discuss in the online learning process" in terms of the quality of lecturer services in providing opportunities to ask/answer/argue in online learning. From the score obtained, it shows that $73.9 \%$ of respondents considered that the lecturer has provided opportunities for students to ask and respond to student questions well. Nevertheless, there are still 3.6\% of respondents who gave negative responses to the quality of lecturer services in providing opportunities to ask and respond to student questions during online learning. Meanwhile, $22.5 \%$ of respondents answered average. 
Moreover, QP3 in table 4 shows the percentage of respondents' answers to statement number 3 "The lecturer explains the 6 forms of assignments given (routine assignments, critical book reports, critical journal reports, mini research, ideas engineering, and projects)". In terms of the items in this statement, $55.9 \%$ of respondents considered that the lecturer has explained 6 forms of assignment to students with good quality. Additionally, there are still $9.01 \%$ of respondents who gave negative responses to the quality of lecturer services in explaining the 6 forms of assignments given to students. Meanwhile, $35.1 \%$ of respondents answered average.

Next, QP4 in table 4 shows the percentage of the respondents' answers to statement number 4 "The lecturer discussed the results of case study assignments (Mini Research)". In terms of the items in this statement, $46.8 \%$ of respondents think that the lecturer has explained 6 forms of assignment to students with good quality. Moreover there are still $13.5 \%$ of respondents who gave negative responses to the quality of lecturer services in discussing the results of case study assignments (Mini Research) that have been carried out by students. Meanwhile, $39.6 \%$ of respondents answered average or average regarding the quality of lecturer services in discussing students' final assignments.

Then, QP5 in table 4 shows the percentage of respondents' answers to statement number 5 "The lecturer facilitates the students in carrying out project assignments to solve problems by conducting FGDs". In terms of the items in this statement, $49.5 \%$ of respondents think that lecturers have facilitated students in carrying out project assignments with good quality. In addition, there are still $20.7 \%$ of respondents who gave negative responses to the quality of the lecturer services in facilitating the students in carrying out project assignments. Meanwhile, $29.7 \%$ of respondents answered average or average regarding the quality of lecturer services in facilitating students to carry out project tasks to solve problems by conducting FGDs. Specifically for this statement, it can be interpreted that online learning is still not maximally carried out by lecturers.

Next, QP6 in table 4 shows the percentage of respondents' answers to statement number 6 "The lecturer acts objectively and is not discriminatory in their assessments." In terms of the items in this statement, $72.1 \%$ of respondents think that the lecturer has acted objectively and not discriminatory in the assessment with good quality. Moreover, there are still $2.7 \%$ of the respondents who gave negative responses to statements related to discriminatory treatment by lecturers during lectures. Meanwhile, $25.2 \%$ of respondents answered that the quality of lecturers was in average.

Finally, QP7 in table 4 shows the percentage of the respondents' answers to statement number 6 "Lecturers complete the number of learning meetings according to the RPS." In terms of the items in this statement, $69.4 .1 \%$ of respondents considered that the lecturer has completed the number of learning meetings according to the RPS. In addition, there are still $3.6 \%$ of respondents who gave negative responses to statements related to this instrument. This shows that there are still a small number of lecturers who do not complete lecture meetings in accordance with the RPS. Meanwhile, $27 \%$ of respondents answered that the quality of lecturers was in average.

The students' perceptions on the learning quality can be used as evaluations for study program institutions in carrying out learning service activities that support independence in the independent campus program. Independence, according to [15], refers to teaching itself and also states that being independent means learning things, the best thing it self. Independence in learning is something that requires special attention in learning. According to [16], independence is not dependence. It is also an impact of learning [17]. 


\section{Conclusion}

Based on the results of research and discussion as described in the previous section, it can be concluded that the Implementation of the Kampus Merdeka Program at PBSI FBS Unimed carried out 2 activities, they are Kampus Mengajar (Campus Teaching) which was attended by 61 students in batch 1 and a decrease in the number of students in batch 2 to 19. Meanwhile, the activity of Merdeka Students' Exchange were implemented based on the collaboration built with the Indonesian Language and Literature Education Study Program from Universitas Negeri Padang UNP), Universitas Sebelas Maret Surakarta (UNS), Universitas Negeri Semarang (UNNES), dan Universitas Negeri Jakarta (UNJ), Universitas Negeri Yogyakarta (UNY), Universitas Negeri Malang (UM), Universitas Pendidikan Indonesia (UPI), and Universitas Negeri Surabaya (UNESA) Moreover, the students' perceptions in online learning, it was found that the level of the students' satisfaction with the lecturer services in online learning was in the category of positive perceptions with an average score of $72 \%$. Meanwhile, the statements related to facilitating the student task problem solving by conducting FGDs were still rated negative with a score of $20.7 \%$. These findings can then be used as a consideration for study program institutions in providing better learning service.

Acknowledgments. The author would like to thank to the entire academic community of the Fakultas Bahasa dan Seni, Unimed who were involved in the implementation of the research, and specifically to the Institute for Research and Community Service, Universitas Negeri Medan related to the BOPTN-2021 funding for the implementation of this research.

\section{References}

[1] Permendikbud Nomor 3 Tahun 2020 tentang Standar Nasional Pendidikan Tinggi.

[2] Fonna N. Pengembangan Revolusi Industri 4.0 dalam Berbagai Bidang. Jakarta: Guepedia Publisher; 2019.

[3] Prayekti P, Budiman MH, Budi UL. Pengaruh Kemandirian Belajar terhadap Hasil Belajar Mahasiswa Bidik Misi Masa Registrasi 2016.1. Tantangan Profesionalisme Guru di Era Digital. Proceeding of Temu Ilmiah Nasional Guru VIII; $26^{\text {th }}$ November 2016; Tangerang Selatan. 2016. p. 143-154.

[4] Arista FS, Kuswanto H. Virtual physics laboratory application based on the Android Smartphone to improve learning independence and conceptual understanding. Int J Instruction. 2018; 11(1):116.

[5] Mulyono D. The influence of learning model and learning independence on mathematics learning outcomes by controlling students' early ability. Int Elect J Math Edu. 2017; 12(3):689-708.

[6] Mukhlis S, Japar M, Maksum A, Adiansha AA. Improving discipline and learning independence of PKn through reinforcement. American J Edu Research. 2018; 6(7):1033-1039.

[7] Nofiani M, Julianto T. Efektivitas Pelaksanaan Program Magang Pembelajaran terhadap Kemampuan TPACK (Technological Pedagogical Content Knowledge) Mahasiswa Calon Guru Biologi FKIP Universitas Muhammadiyah Purwokerto. Proceeding Biology Education Conference; 2018. p. 577-582.

[8] Hastuti AY. Merdeka Belajar: Optimalisasi IT dalam Pembelajaran Ketrampilan Berbicara Bahasa Inggris melalui Video Simulasi Teks Prosedur. Proceeding of Seminar Nasional Pendidikan Implementasi Merdeka Belajar Berdasarkan Ajaran Tamansiswa; $7^{\text {th }}$ March 2020; Sleman. p. 231 240.

[9] Wardhana IP. Konsep Pendidikan Taman Siswa sebagai Dasar Kebijakan Pendidikan Nasional Merdeka Belajar di Indonesia. Proceeding of Seminar Nasional Pendidikan Implementasi Merdeka Belajar Berdasarkan Ajaran Tamansiswa; $7^{\text {th }}$ March 2020; Sleman. p. 112-120. 
[10] Putera LJ, Sugianto R. Perception and Optimism About Two-Semester off-Campus Internship Program of the Policy of Kampus Merdeka-Merdeka Belajar Among University Students. J Languages and Language Teaching. 2020; 8(3):264-275.

[11] Ramadania F, Aswadi D. Blended Learning dalam Merdeka Belajar Teks Eksposisi. J Bahasa, Sastra, dan Pengajarannya. 2020; 5(1):10-21.

[12] Fitriani L, Yudhi A. Study development of digital teaching materials support online learning during Covid-19. The $2^{\text {nd }}$ International Conference on Sciences and Technology Applications (ICOSTA) 2020; $3^{\text {rd }}$ November 2020; Medan. IOP Publishing J. Phys: Conf. Ser; 2020. p. 1-7.

[13] Priatmoko S, Dzakiyyah NI. Relevansi Kampus Merdeka terhadap Kompetensi Guru Era 4.0 dalam Perspektif Experiental Learning Theory. AT- THULLAB. 2020; 4(1):1-15.

[14] Susetyo. Permasalahan Implementasi Kurikulum Merdeka Belajar Program Studi Pendidikan Bahasa Indonesia FKIP Universitas Bengkulu. Proceeding of Seminar Daring Nasional: Pengembangan Kurikulum Merdeka Belajar Program Studi Pendidikan Bahasa Indonesia; $21^{\text {st }}$ October 2020. p. 29-43.

[15] Medlin RG, Butler JL. Thinking skills, academic intrinsic motivation, academic self-concept, and academic independence in homeschooled children. J Unschooling and Alternative Learning. 2018; 12(24):62-90.

[16] Boeree CG. Personality theories: Melacak kepribadian anda bersama psikolog dunia. Yogyakarta: Prisma Sophie; 2013.

[17] Birnbaum MH, Schmidt U. The impact of learning by thought on violations of independence and coalescing. Decision Analysis. 2016; 12(3):144-152. 